\title{
E-WALLET SERVICE INNOVATION, SERVICE DELIVERY, AND CUSTOMER SATISFACTION ON CUSTOMER LOYALTY WITHIN SHOPEEPAY IN INDONESIA
}

\author{
Devona Valencia ${ }^{1}$ \\ Universitas Pelita Harapan, Tangerang, Indonesia \\ devonavalencia@gmail.com \\ Chrisanty V. Layman ${ }^{2}$ \\ Universitas Pelita Harapan, Tangerang, Indonesia \\ chrisanty.layman@uph.edu
}

Received on 27 Januari 2021

Accepted on 31 Maret 2021

\begin{abstract}
Indonesia's fast-growing digital payment industry is encouraging the emergence of new players. In a highly competitive industry and accompanied by COVID-19, e-wallet service providers compete to attract consumers and seller partners to use their services. This study aims to examine the effect of service innovation (SI), service delivery (SD), and customer satisfaction (CS) on customer loyalty (CL) of ShopeePay e-wallet users in Indonesia, especially during the COVID-19 outbreak. This study uses a quantitative method with non-probability sampling, namely judgment sampling, in which respondents are users of ShopeePay e-wallet service in Indonesia. Samples analyzed was 303 respondents with questionnaire data collection technique. The results shows that SI and SD mediated by CS, and CS itself has a positive and significant effect on CL of ShopeePay users in Indonesia. These findings indicate that ShopeePay Indonesia needs to develop SI and SD that meets customer needs and expectations to achieve CL.
\end{abstract}

Keywords: Delivery; Indonesian e-wallet; Innovation; Loyalty; Satisfaction

\section{INTRODUCTION}

\subsection{Research Background}

In an increasingly competitive industrial condition supported by technological advances, companies need to take advantage of technology in the form of digital innovation in company products in order to encourage competitiveness (Isna, 2019), where businesses must be prepared for a new normal or less contact economy situation (Harususilo, 2020), that during the COVID-19 outbreak, consumers avoid physical contact to prevent the spread of the virus so that more transactions are carried out digitally (Musaad, 2020).

Electronic money or electronic wallet SI in Indonesia has made people's lives easier because they are practical, safe, fast, and in accordance with health protocols when the COVID19 pandemic takes place, which does not require direct contact (Supriyanto, 2020). The term innovation is also related to problem solving, where innovation is often used as a solution to new problems or new solutions to old problems (Stenberg, 2017). E-wallet innovation is important because the existence of e-wallet also helps maintain the stability of the country's financial system, where credit interest rates can further decrease and bank liquidity is maintained, and reduce unemployment (Mahlil, 2019). 
Until 2020, in total there are 51 electronic money providers that have received permission from Bank Indonesia, with names that are top of the user's mind, such as ShopeePay, OVO, GoPay, DANA, and LinkAja (Sofuroh, 2020). E-wallet operators benefit from every rupiah contained in consumer digital wallets, which is in the form of bank interest and from a merchant or service provider commission. In a highly competitive industry, e-wallet service providers compete with each other in providing the most attractive offers with the aim of attracting consumers and selling partners to use their digital wallet services so that there is an increase in transactions (Setyowati, 2019).

In a report entitled The Evolution of the Digital Wallet: Driving the Next Wave of Growth by Ipsos, based on the results of a survey conducted in the period December 2019 to January 2020 of 500 respondents (19\% Gen Z, 81\% Millennial) in Indonesia, it was found that to maintain customer loyalty and be sustainable it is important for e-wallet providers to focus on safety, practicality, innovation, and quality of e-wallets (Ipsos, 2020; MSN, 2020). E-wallet service providers who are unable to attract or retain consumers to make transactions will experience defeat, such as the VCash e-wallet service from the telecommunications company Digi in Malaysia which was only two years old when a refund process was carried out for its users until 30 November 2019 (Wong, 2019).

In doing digital SI in the form of e-wallets, organizers must ensure that there are no errors in the server (Yoga, 2020) so that service delivery takes place properly, and ensures the confidentiality of data from each user because digital financial sector is a business that depends on trust (Firmansyah, 2020). By paying attention to these things, it will support the satisfaction and loyalty of a user with the use of their e-wallet.

When COVID-19 pandemic took place, there was a significant increase in the number of contactless payments in Indonesia. The results of McKinsey Global survey showed that there was an increase in contactless payments by $26 \%$ in Indonesia during June 2020 (Awasthi et al., 2020), and this phenomenon is likely to continue even after COVID-19 pandemic ends. The increase in contactless payments during the COVID-19 pandemic occurred because most people prefer to carry out purchasing activities through e-commerce in their respective homes so that more transactions are done digitally (Musaad, 2020).

There are several big players in Indonesia's digital payment industry, namely e-wallets that are full of competition, such as ShopeePay, OVO, GoPay, DANA, and LinkAja, where consumers and transactions are two very important factors to maintain the sustainability of ewallet providers. However, based on the results of three surveys by Snapcart, MarkPlus Inc, and Yougov in 2020, among the five most popular e-wallet application brands in Indonesia, ShopeePay has succeeded in becoming the e-wallet brand with the largest users (68\%) since June 2020 based on respondents' answers, it has had the fastest growth rate since early 2020, the highest and largest market share of transactions and total value of e-wallet transactions in Indonesia (Prasetyo, 2020; Setyowati, 2020; Kontan, 2020). ShopeePay is an entrepreneurial movement from Shopee which is owned by Sea Ltd, which previously only engaged in the marketplace, however, since 2018 it has penetrated into the digital payment field and was inaugurated on August 25, 2020 virtually (Bagas, 2020). ShopeePay currently has the largest number of users with $45 \%$ of orders at Shopee Indonesia are paid using ShopeePay (Henry, 2020).

There are several research studies exploring the adoption of innovations in the digital payment sector, especially e-wallets and mobile wallets. Bagla and Sancheti (2018) showed that cashback, rewards, ease of use, instant transfer of money, high security, and no transaction fees are factors that affect the increasing popularity of digital wallets in India, as well as the sustainability challenges faced by digital wallet providers are caused by a gap between user 
expectations and their satisfaction level. According to Singh et al. (2020), ease of use, usefulness, perceived risk, and attitude are factors that significantly influence user's intention, which then affects user's perceived satisfaction and recommendation for using mobile wallet services in India. Gupta and Singh (2017) discussed the relationship management strategies such as reliability, dedication, conversation and handling of customer issues that affect e-wallet CL. User satisfaction plays a greatest influence on continual use of mobile financial services in Ghana (Adjei et al., 2019).

In Indonesia, Octabriyantiningtyas et al. (2019) discussed the dimensions of service quality that can maintain and improve satisfaction and CL of E-money LinkAja from Telkomsel, namely ease of use, reliability, responsiveness, privacy, and security, where CS which then affects CL is also influenced by handling complaint. Perceived ease of use, perceived benefit and promotion also have a direct and significant effect on repurchase interest of OVO balance (Silaen and Prabawani, 2019). Furthermore, there are several factors that affect the continuance usage of mobile wallets, including trust, flow, and satisfaction, where all three are initiated by product quality (Azizah et al., 2018). Widodo et al. (2019) found that habit influences behavioral intention, performance expectancy, trust, and facilitating conditions to adopt digital wallet in Indonesia. However, previous studies have not yet discussed the effect of service innovation, service delivery, and customer satisfaction on customer loyalty in the e-wallet sector in Indonesia.

\subsection{Literature Review}

\subsubsection{Service Innovation (SI)}

Innovation is one of the most important pillars for many organizations in facing today's competitive environment. Innovation is now the main ingredient for managing global competitiveness (Schwab, 2011). The term innovation comes from the Latin "innovare" which means "to be new" (Stenberg, 2017). According to Trott $(2017$, p. 16), "innovation is the management of all activities involved in the process of creating ideas, developing technology, creating and marketing new (or improved) products or manufacturing processes or equipment."

According to Schumpeter (1934) in Ganzer et al. (2017), "innovation is the act of innovating and creating a process or something new, which promotes disruption of an outdated economic system while allowing new things to emerge." Schumpeter's notion describes what is called "creative destruction." Since the start of 4.0 industrial revolution era which focuses on the use of technology and internet in industry, many countries have begun to focus on creative and innovative economies (Sugiarto, 2018). Since 2015, the Indonesian government has focused on developing Indonesia's creative industries (Hasnan, 2019), where this industry is an industry that relies on creativity as its main resource (Writer, 2018). Creativity and innovation are linked by a creative process with the aim of producing something of value that can be traded, developed and exploited commercially (Taylor, 2017). The term innovation is also related to problem solving, where innovation is often used as a solution to new problems or new solutions to old problems (Stenberg, 2017).

In terms of service is an important economic sector in the world economy, both in developed and most developing countries. SI has a transformative role in the economy in various ways, namely increasing productivity in the service sector, increasing the productivity of other sectors that use services, and enabling increased social and economic performance, especially in developing countries (Djellal and Gallouj, 2010; L. Rubalcaba and Kox, 2007 in Rubalcaba et al., 2016). E-wallet organizers can take advantage of technology to provide SI to users. One example of SI is face recognition. This SI will also serve as a way to attract busy 
individuals who like practicality to continue using e-wallets in making transactions in order to support the survival and growth of e-wallet organizers.

\subsubsection{Service Delivery (SD)}

Traditionally, SD has been defined as "a person-to-person meeting between buyers and sellers which can be described as a goal-oriented interaction between the dyad and the goal" (Solomon et al., 1985 in Furunes and Mkono, 2019), where success lies in quality subjective service experience. According to the Cambridge English Dictionary (2020), SD is "the act of providing service to customers." According to Lovelock and Wright (2002) in Martins and Ledimo (2015), SD refers to "the actual delivery of services and products to customers or clients." It is important for every company to focus on SD, where in today's competitive industrial situation, customers can easily move to competitors if the services provided are not in accordance with their expectations. Only companies that improve their services and operational systems can survive the challenges threatened by the rapidly changing waves of globalization, consolidation, privatization, deregulation, and technology (Uchenna et al., 2019). Through SD, a company can also retain existing customers by offering a good and valuable service experience (PricewaterhouseCoopers, 2007).

An understanding of customer reactions to SD time is one of the most important service that will have a major impact on CS (Dholakia and Zhao, 2010). Johnston et al. (2012, p. 102) in the book Service Operations Management: Improving SD wrote that by influencing customer perceptions and expectations of SD, CS can be managed to a certain extent. In building an effective service sector, SD from a business must be of high quality, accessible anywhere, comprehensive and consistent, and cost-effective (Blackmore et al., 2015). The use of modern technology can shape customer service and experience as well as influence customer service expectations and behavior (Rafaeli et al., 2016).

\subsubsection{Customer Satisfaction (CS)}

According to Cambridge English Dictionary (2020), "satisfaction is the pleasant feeling you get when you receive something you want, or when you have done something you want to do," then for "CS is a measure of how happy customers are when they do business with a company," (Cambridge English Dictionary, 2020). Based on an article on the website of American Society for Quality on July 15, 2020 with the article title What is CS?, CS is defined as "a measure that determines how happy customers are with a company's products, services, and capabilities." According to Terpstra et al. (2013), CS refers to "someone's satisfaction with a product, service, or supplier." CS can also be defined as "a positive emotional reaction after purchasing a product or service," (May et al., 2017 in Othman et al., 2020).

In creating and maintaining a competitive advantage, and to grow and succeed, every company needs to pay great attention to CS. According to Hague and Hague (2016) in Khadka and Maharjan (2017), satisfied customers will usually make more purchases from companies and become a network to reach other potential customers by sharing their experiences.

The triangle law of customer relationship management explains that CS is the customer experience minus customer expectations (Tao, 2014). To meet or exceed CS, a company needs to focus on the products offered along with their features, functions, and reliability (Khadka and Maharjan, 2017). In order to improve CS, companies must jointly eliminate the causes of direct complaints, namely by ensuring that their products and services are of excellent quality (Othman et al., 2020). In particular, employee job satisfaction has an important effect on CS, where satisfied employees tend to be more productive and provide better service to customers so that they can significantly increase business profitability (Pantouvakis and Bouranta, 2013). 


\subsubsection{Customer Loyalty (CL)}

Krumay and Brandtweiner (2010) stated that "CL is seen as one of the key factors in company success." Oliver (1999) in Fraering and Minor (2013) stated that the only important customers are those who are loyal, where very satisfied customers can remain regularly defected to the competition (Kapferer, 2005; Mittal and Lassar, 1998). Loyal customers will show attachment and commitment to the company, where they will not be interested in offers from competitors (So et al., 2013 in Kandampully et al., 2015). Loyal customers will be willing to pay more and express higher purchase intentions (Evanschitzky et al., 2012 in Kandampully et al., 2015).

Basically, there are four types of CL in the market, namely no loyalty, inertia loyalty, latent loyalty, and premium loyalty (J. Griffin, 2002 in Ranabhat, 2018). Customers who cannot survive with products or services from certain companies to fulfill their needs and desires are known as no loyalty customers. Customers who have a low level of engagement but make high repeated purchases of products or services are included in inertia loyalty. Customers with high and positive attitudes towards certain suppliers but making low repeat purchases are known as latent loyalty customers. Customers with high levels of engagement and who make repeated purchases of products and services are known as premium loyalty customers. Premium loyalty customers often recommend the goods or services they buy to other people (their family, friends and relatives).

There are several factors and determinants that affect CL (Lawton, 2016), namely core offer, satisfaction, elasticity, switching costs, demographics, and the digital environment. Lawton (2016) also showed several ways, such as simplicity, social media, online customer service, loyalty programs, gamification, prominent reviews, and payment options to help build trust and CL online.

\subsubsection{Relationship Between SI and SD}

YuSheng and Ibrahim (2019) found that SI at commercial banks in Ghana has a significant positive effect on SD. This is also supported by previous research, from Musara and Fatoki (2010) that technological innovation in the banking service sector has resulted in increased efficiency and reduced banking costs for customers of Alice city in South Texas. Wambugu et al. (2016) stated that innovation in the public sector in Kenya has a major influence on SD, such as reducing time for SD, and increasing accountability and transparency. Then, it was found that there was a direct and positive relationship between innovation and performance in various service sectors in China (Lin, 2011) and Italy (Ordanini and Parasuraman, 2011), where companies that clearly define their innovation processes for services can be faster and more successful in developing new services. In Indonesian telecommunications industry it was found that innovation has an effect on improving service quality, and prevents customers from switching to other operators, where good innovations can result in continuous CS and high CL (Dachyar et al., 2013). Therefore, it is hypothesized that:

\section{H1. SI has a positive and significant effect on SD of ShopeePay users in Indonesia.}

\subsubsection{Relationship Between SI and CS}

YuSheng and Ibrahim (2019) found that SI at commercial banks in Ghana has a significant positive effect on CS. These findings are in line with previous studies, Ameme and Wireko (2016) found a positive relationship between CS and technological innovations. Meanwhile, 
Mahmoud et al. (2017) stated that SI helps in achieving several levels of CS, where SI that creates customer value positively and significantly affects CS in the telecommunications network industry in Ghana. Kurniawan et al. (2019) concluded that SI has a positive effect on CS at Indihome in Central Java, where satisfaction can be realized along with an increase in service quality. These results are also supported by previous studies, Mahmoud (2017), Bellingkrodt (2016), Ganesan (2016), and Tsai (2012) in Kurniawan et al. (2019), who reported that SI has a positive effect on CS. Mercado (2013) in Kurniawan et al. (2019) stated that focusing on SI process and setting higher innovation efforts leads to CS. In the telecommunications service industry in Ghana, Diaw and Asare (2018) proved a relationship between innovation and satisfaction and customer retention. Therefore, it is hypothesized that: H2. SI has a positive and significant effect on CS of ShopeePay users in Indonesia.

\subsubsection{Relationship Between SD and CS}

YuSheng and Ibrahim (2019) found that SD at commercial banks in Ghana has a positive effect on CS, where banks offer quality SD to customers in order to establish a positive relationship between banks and their customers. Seesaiprai (2016) reported that service quality delivered to the car care business in Bangkok has an impact on CS more than SI and perceived value. Chen et al. (2011) found that CS at home delivery service providers in Taiwan is positively correlated with various types of service convenience (i.e. decision convenience, access, transactions, benefits, and post-benefits), where the more service convenience services that is expected provided or even exceeding the customers' requirements, the higher the CS. Narteh (2015) showed that convenience, reliability, ease of use, responsiveness, and fulfillment of ATMs in Ghana predict CS. Amankwah et al. (2019) found that patients in Ghana evaluate health care services based on personal experience thus making a user-oriented approach to health care delivery important for improving overall patient satisfaction. Therefore, it is hypothesized that:

\section{H3. SD has a positive and significant effect on CS of ShopeePay users in Indonesia.}

\subsubsection{Relationship Between SI and CL}

YuSheng and Ibrahim (2019) found that SI at commercial banks in Ghana has a significant and direct positive effect on CL, mediates the relationship between SD, CS and CL, and has a significant indirect relationship with CL through SD, where these results confirm the findings of previous studies (Ameme and Wireko, 2016; Nguyen et al., 2014) in the banking sector where innovation can effectively affect customers' satisfaction and loyalty. Seesaiprai (2016) showed that SI in the car care business in Bangkok has a direct impact on CL. Senbabaoglu (2017) reported that SI content on shopping sites in Turkey has a significant and positive effect on perceived overall service quality, CL, and perceived customer value. Wu (2014) stated that SI in the context of digiservice in Taiwan can help organizations improve CL. Therefore, it is hypothesized that:

\section{H4. SI has a positive and significant effect on CL of ShopeePay users in Indonesia.}

\subsubsection{Relationship Between CS and CL}

YuSheng and Ibrahim (2019) found that CS at commercial banks in Ghana has a positive effect on CL. CS at banks in Ghana (YuSheng and Ibrahim, 2019; Ameme and Wireko, 2016) and China (Nguyen et al., 2014) mediate a positive relationship between SI and CL. Leninkumar (2017) stated that there is a significant positive relationship between CS and CL in the context of commercial banking in Sri Lanka. Seesaiprai (2016) showed that CS in the car care business in Bangkok has a direct impact on CL. Özkan et al. (2019) reported that CS 
in Turkish banking industry and service quality have an effect on perceived value, corporate image and reputation, and CL. Fernandes and Solimun (2018) found a positive relationship between CS and CL services for cellular phone providers in Malang, where the fulfillment of expectations, suitability and achievement of services provided by cellphone providers will result in CS which at ultimately will result in CL. Al-Msallam (2015) reported that CS at banks in Syria has a positive impact on CL. Therefore, it is hypothesized that:

\section{H5. CS has a positive and significant effect on CL of ShopeePay users in Indonesia.}

\subsubsection{Relationship Between SD and CL}

YuSheng and Ibrahim (2019) showed a significant and direct positive relationship between SD and CL, and reported that SD at commercial banks in Ghana has a positive indirect effect on CL through CS, whereby offering quality SD will create a positive relationship with bank customers. In addition, it was found that SD mediates a significant positive relationship between SI and CL at banks in Ghana (YuSheng and Ibrahim, 2019; Ameme and Wireko, 2016) and China (Nguyen et al., 2014). Seesaiprai (2016) showed that SI, service quality, perceived value, and CS in the car care business in Bangkok have a direct impact on CL. Mary and Henshaw (2020) found that timeliness and responsiveness are SD strategies to predict CL in terms of repeat purchases and word-of-mouth. Nienaber (2010) reported that if the customer is satisfied with SD and meets their expectations, there will be greater CL and profit for the company. Therefore, it can be formulated in this study:

H6. SD has a positive and significant effect on CL of ShopeePay users in Indonesia.

Based on these hypotheses, the framework of the research is presented on figure 1 below.

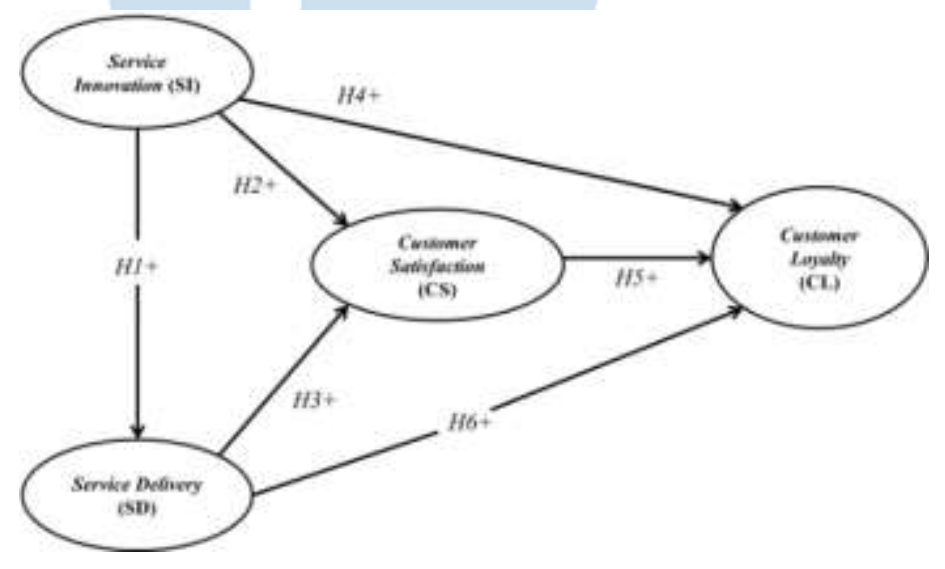

Figure 1. Research Model

Source: YuSheng and Ibrahim (2019)

\section{METHODOLOGY}

\subsection{Data and Sample}

The research method used is quantitative. Research population is individual users of ShopeePay e-wallet in Indonesia. Non-probabilistic sample design, namely judgment sampling, was used to select e-wallet users, where the sample criteria for this study were men and women aged 17 years and over, domiciled in Indonesia, and users of ShopeePay e-wallet service for at least one month.

Primary data were collected through a self-administered questionnaire that was sent online in September and October 2020 (cross-sectional). The questionnaire includes four variables with a total of 30 indicators adapted from questions in previous similar studies with discussions 
of SI, SD, CS, and CL (Table 1). Each indicator is measured using a five-point Likert scale, where point $1=$ strongly disagree up to point $5=$ strongly agree. There was a change in the Likert scale points used to measure indicators of CS and CL variables, which were previously seven points in a similar study before, to a five-point Likert scale so that respondents did not experience difficulties when filling out questionnaires and minimizing errors when editing data. In compiling the questionnaire, the author first translates indicators from English journal articles into Indonesian using double-back translation with modification procedure. The questionnaire design used positive and negative closed-ended questions and consisted of seven parts. The first part contains title and opening paragraph which aims to explain the purpose of this questionnaire and ensure that respondent is a ShopeePay user, the second part measures the demographic characteristics of respondent, the third to sixth section measures the four variables (SI, SD, CS, and CL), and the seventh section contains expressions of gratitude. After going through reliability and validity tests, it was found that there were 21 indicators that were reliable and valid in this study.

Table 1. Constructs Items

\begin{tabular}{|c|c|c|c|c|}
\hline Constructs & Label & Cronbach's $\alpha$ & $\begin{array}{l}\text { No. of } \\
\text { items }\end{array}$ & Source \\
\hline Service Innovation & SI & 0,796 & 3 & Mahmoud et al. (2018) \\
\hline Service Delivery & SD & 0,938 & 4 & $\begin{array}{l}\text { Ba and Johansson (2008, in Kumar } \\
\text { et al., 2020) }\end{array}$ \\
\hline Customer Satisfaction & CS & 0,941 & 6 & $\begin{array}{l}\text { Nefat et al. (2012), Bhattacherjee } \\
\text { (2001, in Othman et al., 2020), } \\
\text { Dawi et al. (2018) }\end{array}$ \\
\hline Customer Loyalty & CL & 0,919 & 8 & $\begin{array}{l}\text { Cheng et al. (2008, in Thuy and } \\
\text { Hau, 2010), Özkan et al. (2019) }\end{array}$ \\
\hline
\end{tabular}

\subsection{Data Analysis}

The number of respondents in this study were 354 people, however, the valid respondent data that could be used for analysis were 303 after initial filtering and data cleaning. The collected data were analyzed using the help of SPSS Statistics 26 and SPSS Amos 26 Graphics software. Data were filtered for outliers or other variations in the data set via the Mahalanobis distance in SPSS Statistics 26. Hypotheses were tested using structural equation modeling (SEM), SEM is a "confirmation procedure, in which the researcher tests a formulated model a priori," (Blunch, 2008, p. 98). The method of estimating minimum sample size that is widely used in SEM statistical tests is the "10 times rule" method by Hair et al. (2011), this rule is built on the assumption that sample size must be greater than 10 times the number of indicators that point to the latent variables in the model. In this study, at the beginning author used the number of indicators as many as 30 items so that with the number of indicators 30 times 10, the minimum sample size needed was 300 . Based on the existing theories regarding the minimum sample size, the author decided that the minimum sample size taken in this study consisted of 300 respondents to follow an acceptable level of sample size for SEM analysis and to achieve valid statistical tests. Validation is done through content and construct validation, where content validity is done by asking for help from five target respondents, namely ShopeePay users in Indonesia, to try to fill out the questionnaire that has been developed as well as to check the existing indicators of the research variables. 


\subsection{Respondent Profile}

Several demographic variables involved in this study including age, gender, domicile, employment status, monthly income, educational background, duration of using ShopeePay and type of use of ShopeePay in Shopee application, and these results are summarized in Table 2. Seen from gender, the number of respondents is dominated by women with a percentage of $72.9 \%$ or as many as 221 people. Based on age, respondents were dominated by generation $\mathrm{Z}$ with the age of 17-24 years as many as 285 people or a percentage of $94.1 \%$. In accordance with the criteria of the research subject that the respondent must be domiciled in Indonesia, the respondents of this study were spread across the islands of Sumatera, Java, Kalimantan, Sulawesi and Bali, where the majority of respondents were domiciled in Palembang area with a total of 99 people (32.7\%), followed by Tangerang with 87 people $(28.7 \%)$, and then Jakarta with 64 people $(21.1 \%)$. In the category of employment status, the majority of respondents were students with a total of 240 people (79.2\%). In terms of monthly income, the majority of respondents as many as 80 people $(26.4 \%)$ had an income of IDR 1,000,000.00-IDR $2,500,000.00$, followed by 69 people $(22.8 \%$ ) each having an income <IDR 1,000,000.00 and IDR 2,500,001.00-IDR 4,000,000.00. In the recent education background category, 119 respondents $(39.3 \%)$ have high school education, and the majority of respondents as many as 170 people $(56.1 \%)$ have a Bachelor's degree (S1). Based on the period of use, the majority of respondents as many as 120 people (39.6\%) have used ShopeePay for more than 1 year. In terms of types of use, the majority of respondents totaling 256 people $(84.5 \%)$ use ShopeePay to buy products at Shopee.

Table 2. Demographics of Respondents

\begin{tabular}{|c|c|c|c|}
\hline Variable & Category & Frequency & $\%$ \\
\hline \multirow[t]{2}{*}{ Gender } & Male & 82 & $27.1 \%$ \\
\hline & Female & 221 & $72.9 \%$ \\
\hline \multirow[t]{6}{*}{ Age } & $17-24$ & 285 & $94.1 \%$ \\
\hline & $25-32$ & 9 & $3.0 \%$ \\
\hline & $33-40$ & 2 & $0.7 \%$ \\
\hline & $41-48$ & 2 & $0.7 \%$ \\
\hline & $49-56$ & 5 & $1.7 \%$ \\
\hline & $>56$ & 0 & $0.0 \%$ \\
\hline \multirow[t]{14}{*}{ Domicile } & Jakarta & 64 & $21.1 \%$ \\
\hline & Bogor & 2 & $0.7 \%$ \\
\hline & Depok & 1 & $0.3 \%$ \\
\hline & Tangerang & 87 & $28.7 \%$ \\
\hline & Bekasi & 11 & $3.6 \%$ \\
\hline & Palembang & 99 & $32.7 \%$ \\
\hline & Bali & 4 & $1.3 \%$ \\
\hline & Bandung & 5 & $1.7 \%$ \\
\hline & Bangka & 1 & $0.3 \%$ \\
\hline & Batam & 3 & $1.0 \%$ \\
\hline & Belitung & 1 & $0.3 \%$ \\
\hline & Kalimantan & 2 & $0.7 \%$ \\
\hline & Kudus & 1 & $0.3 \%$ \\
\hline & Makassar & 1 & $0.3 \%$ \\
\hline
\end{tabular}




\begin{tabular}{|c|c|c|c|}
\hline & Malang & 1 & $0.3 \%$ \\
\hline & Medan & 4 & $1.3 \%$ \\
\hline & Pekanbaru & 11 & $3.6 \%$ \\
\hline & Surabaya & 3 & $1.0 \%$ \\
\hline & Yogyakarta & 2 & $0.7 \%$ \\
\hline \multirow[t]{9}{*}{ Employment status } & Student / college student & 240 & $79.2 \%$ \\
\hline & Civil servant & 0 & $0.0 \%$ \\
\hline & Private employee & 36 & $11.9 \%$ \\
\hline & Entrepreneur & 21 & $6.9 \%$ \\
\hline & Housewife & 2 & $0.7 \%$ \\
\hline & Lecturer & 1 & $0.3 \%$ \\
\hline & Fresh graduate & 1 & $0.3 \%$ \\
\hline & Makeup artist & 1 & $0.3 \%$ \\
\hline & Music teacher & 1 & $0.3 \%$ \\
\hline \multirow[t]{8}{*}{ Monthly income } & $<$ Rp1.000.000,00 & 69 & $22.8 \%$ \\
\hline & Rp1.000.000,00-2.500.000,00 & 80 & $26.4 \%$ \\
\hline & Rp2.500.001,00-4.000.000,00 & 69 & $22.8 \%$ \\
\hline & Rp4.000.001,00-5.500.000,00 & 41 & $13.5 \%$ \\
\hline & Rp5.500.001,00-7.000.000,00 & 19 & $6.3 \%$ \\
\hline & Rp7.000.001,00-8.500.000,00 & 5 & $1.7 \%$ \\
\hline & $\begin{array}{l}\text { Rp8.500.001,00- } \\
10.000 .000,00\end{array}$ & 7 & $2.3 \%$ \\
\hline & $>$ Rp10.000.000,00 & 13 & $4.3 \%$ \\
\hline \multirow[t]{6}{*}{ Recent Educational Background } & Junior high school & 3 & $1.0 \%$ \\
\hline & Senior High School & 119 & $39.3 \%$ \\
\hline & Diploma & 8 & $2.6 \%$ \\
\hline & Bachelor & 170 & $56.1 \%$ \\
\hline & Master & 3 & $1.0 \%$ \\
\hline & Doctorate & 0 & $0.0 \%$ \\
\hline \multirow[t]{5}{*}{ Period of Time in Using ShopeePay } & $<1$ Month & 40 & $13.2 \%$ \\
\hline & 1-4 Months & 57 & $18.8 \%$ \\
\hline & 5-9 Months & 53 & $17.5 \%$ \\
\hline & 10-12 Months & 33 & $10.9 \%$ \\
\hline & $>1$ Year & 120 & $39.6 \%$ \\
\hline \multirow{3}{*}{$\begin{array}{l}\text { Types of Use of ShopeePay in Shopee } \\
\text { Applications }\end{array}$} & Sell products on Shopee & 1 & $0.3 \%$ \\
\hline & Buy products on Shopee & 256 & $84.5 \%$ \\
\hline & $\begin{array}{l}\text { Sell and buy products on } \\
\text { Shopee }\end{array}$ & 46 & $15.2 \%$ \\
\hline
\end{tabular}

\subsection{Reliability and Validity of the Measurement Model}

All variables return Cronbach's $\alpha$ above 0.70 , indicating these measures are highly reliability of each construct. The validity measurement in this study was carried out using construct validation, namely convergent validity and discriminant validity (Sekaran and Bougie, 2016). Convergent validity is determined by ensuring that for each variable the average variance extracted (AVE) value is> 0.5 and composite reliability (CR)> 0.7 (Hair et al., 2014). The 
criteria for discriminant validity is the value of AVE> squared correlations (Fornell and Larcker, 1981). Table 3 shows that the data have good convergent and discriminant validity and fit the criteria.

Table 3. Discriminant Validity

\begin{tabular}{lccccc}
\hline \multicolumn{2}{l}{ Discriminant Validity } & Factor Correlations & Correlations Squared & AVE1, AVE2 \\
\hline SI & $<->$ & SD & -0.131 & 0.017 & $0.597,0.791$ \\
SI & $<->$ & CS & 0.479 & 0.229 & $0.597,0.729$ \\
SD & $<-->$ & CS & 0.181 & 0.033 & $0.791,0.729$ \\
SI & $-->$ & CL & 0.509 & 0.259 & $0.597,0.596$ \\
CS & $-->$ & CL & 0.672 & 0.452 & $0.729,0.596$ \\
SD & $-->$ & CL & -0.193 & 0.037 & $0.791,0.596$ \\
\hline
\end{tabular}

\section{RESULT AND DISCUSSION}

The results of the structural model for testing research hypotheses related to direct effects are presented in Table 4 and the indirect effect through the mediating effect test is presented in Table 5.

Table 4. Structural Model Results: Direct Effects

\begin{tabular}{|c|c|c|c|c|c|}
\hline Hypothesis & Relationship & Estimate & S.E. & C.R. & $\begin{array}{c}\text { Direct effect } \\
\text { p-value }\end{array}$ \\
\hline H1 & SI-SD & -0.19 & 0.093 & $2.048^{-}$ & 0.041 \\
\hline $\mathrm{H} 2$ & SI-CS & 0.372 & 0.047 & 7.86 & $* * *$ \\
\hline $\mathrm{H} 3$ & SD-CS & 0.124 & 0.028 & 4.436 & $* * *$ \\
\hline $\mathrm{H} 4$ & SI-CL & 0.144 & 0.051 & 2.84 & 0.005 \\
\hline H5 & CS-CL & 0.79 & 0.088 & 8.937 & $* * *$ \\
\hline H6 & SD-CL & 0.177 & 0.031 & 5.751 & $* * *$ \\
\hline
\end{tabular}

Notes: SI, service innovation; SD, service delivery; CS, customer satisfaction; CL, customer loyalty. $* * *$ Significant at 0.001

Table 5. Structural Model Results: Indirect Effects

\begin{tabular}{lcccccc}
\hline Relationship & Estimate A & Estimate B & S.E.a & S.E.b & S.E.ab & Zscoreab \\
\hline SI-SD-CL & -0.19 & -0.177 & 0.093 & 0.031 & 0.017 & 1.924 \\
SI-CS-CL & 0.372 & 0.79 & 0.047 & 0.088 & 0.049 & 5.937 \\
SD-CS-CL & 0.124 & 0.79 & 0.028 & 0.088 & 0.025 & 3.971
\end{tabular}

Notes: SI, service innovation; SD, service delivery; CS, customer satisfaction; CL, customer loyalty. Zscore significant at $>+-1.96$

The results in Table 4 indicate that three of the six hypotheses proposed in this study are accepted. First, H1 shows the insignificant effect of SI on SD $(p=0.041)$. The unstandardized estimate value of -0.19 indicates that SI affects the dependent variable SD by -0.19 . The unstandardized estimate value -0.19 and $p$-value $(p=0.041)$ indicate that there is a non-positive and insignificant relationship between SI and SD, which means that $\mathrm{H} 1$, namely SI has a positive and significant effect on the SD of ShopeePay users in Indonesia is rejected. H2, namely SI has a positive and significant effect on CS of ShopeePay users in Indonesia is accepted $(\mathrm{p}=0.000)$. The unstandardized estimate value of 0.372 shows that SI affects the 
dependent variable CS by 0.372 . The unstandardized estimate value of 0.372 and the p-value $(\mathrm{p}=0.000)$ indicate that there is a positive and significant relationship between SI and CS.

H3, namely SD has a positive and significant effect on CS of ShopeePay users in Indonesia is accepted $(\mathrm{p}=0.000)$. The unstandardized estimate value of 0.124 indicates that SD affects the dependent variable CS by 0.124 . The unstandardized estimate value of 0.124 and p-value $(\mathrm{p}=0,000)$ also shows that there is a positive and significant relationship between SD and CS. $\mathrm{H} 4$ shows the insignificant effect of SI on CL $(\mathrm{p}=0.005)$. The unstandardized estimate value of 0.144 shows that SI affects the dependent variable CL by 0.144 . The unstandardized estimate value of 0.144 and $p$-value $(p=0.005)$ indicates that there is an insignificant positive relationship between SI and CL, which means that H4, namely SI has a positive and significant effect on CL of ShopeePay users in Indonesia is rejected. In addition, H5, namely CS has a positive and significant effect on CL of ShopeePay users in Indonesia is accepted $(p=0.000)$. The unstandardized estimate value of 0.79 indicates that CS affects the dependent variable CL by 0.79 . Finally, H6, which is SD has a positive and significant effect on CL of ShopeePay users in Indonesia is rejected ( $\mathrm{p}=0.000$ and unstandardized estimate $=-0.177)$.

First, based on the results of data analysis, it was found that service innovation (SI) had a non-positive and insignificant effect on service delivery (SD) of ShopeePay e-wallet users in Indonesia. SI from ShopeePay Indonesia which is not free from errors in the system causes the SD process to the user to be disrupted and not positively affected. Ciuchita et al. (2019) discussed that when e-SI was introduced, customers viewed change as a challenge, namely losses that must be avoided or profits that must be pursued. Ngo and O'Cass (2013) based on the results of data analysis taken from a survey of service companies in Australia, found that customer participation mediates the relationship between technical innovation capability and service quality, as well as non-technical innovation capability and service quality. In the relationship between SI and SD, ShopeePay e-wallet in Indonesia may need to pay attention to and involve customer participation properly so that SI can influence the SD of ShopeePay users positively and significantly.

Second, it was found that service innovation (SI) has a positive and significant effect on customer satisfaction (CS) of ShopeePay e-wallet users in Indonesia. Based on a survey by Ipsos entitled "Satisfaction, Perception, and Loyalty of Digital Wallet Users in Indonesia" which was conducted in October 2020 with a sample of up to a thousand respondents from all over Indonesia, it was found that the satisfaction aspect of ShopeePay e-wallet brand was ranked first for user satisfaction with a score $82 \%$, more than other players, such as OVO (77\%), GoPay (71\%), DANA (69\%), and LinkAja (67\%) (Agung, 2020). According to Ipsos Associate Project Director in Indonesia Indah Tanip in Agung (2020), there are several factors that cause ShopeePay user satisfaction to be higher than other e-wallet brands, such as services that are easy to use, easy to top up, real time top up time, and many promotional offers when used. Ease of use of services and top up of ShopeePay e-wallet is supported by the existence of a continuous SI and then followed by an increase in CS. This finding confirms the findings of previous studies, Ameme and Wireko (2016) showed that there is a significant relationship between CS and technological innovations in the Ghana banking industry, and it is reported that SI has a positive effect on CS of Internet provider Indihome in Central Java (Kurniawan et al., 2019) and the hospitality industry in Indonesia (Mihardjo et al., 2019).

Third, this study found that service delivery (SD) has a positive and significant effect on customer satisfaction (CS) of ShopeePay e-wallet users in Indonesia. According to Indah Tanip in Agung (2020), one of the factors that causes ShopeePay user satisfaction to be higher than other e-wallet brands is real time top up time. Real time top up time system or receiving money at the same time when transfers are made is supported by a structured SD from the ShopeePay 
e-wallet at Indonesia which then increased the CS. One of the most important service attributes for electronic banking is speed of the transaction (Joseph and Stone, 2003 in Demoulin and Djelassi, 2013), which, if considered, will have a major impact on CS (Dholakia and Zhao, 2010). This finding is in line with Salameh et al. (2018) who showed that service quality has a significant effect on CS in the context of m-commerce in Jordan, Estiri et al. (2011) who showed that service quality is positively related to CS in Iranian Islamic retail banking, Chu et al. (2012) who found that e-banks in Taiwan should focus on service quality to improve CS, Amin (2016) who showed that service quality of internet banking has a positive relationship with e-CS on commercial banks in Malaysia, and Minh and Huu (2016) who reported that the effect of service quality on CS is statistically significant in the Vietnamese Retail Banking Sector.

Fourth, this study revealed that service innovation (SI) has a positive and insignificant effect on customer loyalty (CL) of ShopeePay e-wallet users in Indonesia. These findings are in accordance with Schulte-Brüggemann et al. (2018) who reported that firm innovation had a positive and insignificant effect on CL. The full mediating effect of CS was found in the relationship between SI and CL in this study (Zscore 5,937), where the influence of SI on CL that was previously insignificant needs to go through CS first to then be transferred to CL. This finding is in line with YuSheng and Ibrahim (2019) who found a significant indirect relationship between SI and CL through CS. Based on a survey by Ipsos in October 2020, it was found that ShopeePay was the digital wallet that made it easier for users to shop online with a percentage of $44 \%$ (Firmansyah, 2020). The ease of using ShopeePay Indonesia in online shopping is supported by SI such as face recognition, which then boosts user satisfaction levels with Shopeepay according to Ipsos Associate Project Director in Indonesia Indah Tanip. This level of satisfaction in the end also encourages CL, where users are willing to recommend ShopeePay e-wallet brand in Indonesia. These findings imply that although SI can positively affect CL, it can only be done indirectly via CS.

Fifth, this study found that customer satisfaction (CS) has a positive and significant effect on customer loyalty (CL) of ShopeePay e-wallet users in Indonesia. The findings from the Ipsos survey in October 2020 showed that CL of ShopeePay users in Indonesia is connected to CS, where ShopeePay e-wallet is ranked first for user satisfaction (82\%), and makes ShopeePay's net promoter score (NPS) score which is used to understand how CL deals with an electronic wallet brand being positively influenced and successfully superior to other digital wallet brands $(+42 \%$ ) (Agung, 2020). NPS can measure user reactions to service usage, where the more satisfied and loyal users are, the more likely they are to recommend the product to others. This finding is in line with Amin (2016) which showed that there is a positive relationship between e-CS and e-loyalty at commercial banks in Malaysia, Abror et al. (2019) which showed that CS is a significant factor for CL in Islamic bank customers in West Sumatera, Omoregie et al. (2019) who showed that CS has the most significant influence on CL in the Ghana retail banking industry, Minh and Huu (2016) who showed that CS is an important antecedent of CL in the Vietnamese Retail Banking Sector, and Antanegoro et al. (2017) who found that CS has a significant positive effect on CL KKB BCA Cilegon Branch.

Sixth, this study found that service delivery (SD) has a significant non-positive effect on customer loyalty of ShopeePay e-wallet users in Indonesia. These findings are in line with Kumar et al. (2011) who found that when operations performance is negatively affected by increased demand, there is a negative impact on CL. The partial mediating effect of customer satisfaction was found in the relationship between SD and CL of this study (Zscore 3,971), where the effect of SD on CL that was previously not positive needed to go through CS first to then be transferred to be positive on CL. This finding is in line with Suhartanto et al. (2019) 
who found a partial mediation role from CS in the relationship between e-service quality and online loyalty of online food delivery service customers in Bandung, and Kusdibyo and Februadi (2019) who found that CS positively mediated the relationship between e-service quality and loyalty in the context of online shopping in Indonesia. These findings imply that although SD can significantly influence CL, the formation of a positive relationship can only be done indirectly through CS, where ShopeePay e-wallet users who are satisfied with the digital transaction experience offered by ShopeePay Indonesia will not hesitate to continue using ShopeePay when requires e-wallet service. In order to improve CS, companies must jointly eliminate the causes of direct complaints, namely by ensuring that their products and services are of excellent quality (Othman et al., 2020).

This study also found that the full mediation role of SD in the relationship between SI and $\mathrm{CL}$ was not significant because it had a $\mathrm{Z}$ score of 1.924 which is against the criteria for a $\mathrm{Z}$ score $>$ of +-1.96 (Budiman, 2015), where one of the factors that causes this mediation effect is insignificant, namely the absence of direct or indirect relationship between SI (independent variable) and SD (mediator variable) in the context of ShopeePay e-wallet users in Indonesia so that the influence of SI on CL cannot be transferred through SD. Shopee e-commerce updates its application quite frequently and ShopeePay e-wallet in Indonesia is quite innovative in following industry trends however, based on complaints from ShopeePay users it was found that withdrawing or disbursing ShopeePay funds to bank accounts cannot be done directly and requires considerable time between one to two days, in which the service system is different from other e-wallet players, such as OVO, DANA, and GoPay, which make a policy that top ups and transfers are done in real time.

\section{CONCLUSION}

\subsection{Conclusion}

This study examines the effect of service innovation (SI), service delivery (SD), and customer satisfaction (CS) on customer loyalty (CL) in the context of ShopeePay e-wallet services in Indonesia. Using data from a survey of 303 ShopeePay e-wallet users in Indonesia, the test results show a positive relationship between SI, SD and CS with CL on ShopeePay ewallet in Indonesia. This research provides empirical knowledge to ShopeePay e-wallet service providers in Indonesia, especially managers in improving their SD by adopting an innovative SD strategy that involves users participation, which will then improve the relationship between ShopeePay and users in Indonesia in the form of CS and CL. Focus and consistency of the application of entrepreneurship by companies in terms of SI, SD, and CS are some of the main keys to getting CL, where only entrepreneurial companies will think innovatively in creating innovative services to achieve CL so that businesses can win in competition in the market and sustainable.

Based on the results of hypothesis testing and the discussion previously described, the following conclusions can be drawn.

- The Effect of SI on SD of ShopeePay users in Indonesia

SI does not have a positive and significant effect on the SD of ShopeePay users in Indonesia, which means $\mathrm{H} 1$ is rejected.

- The Effect of SI on CS of ShopeePay users in Indonesia

SI has a positive and significant effect on CS of ShopeePay users in Indonesia, which means $\mathrm{H} 2$ is accepted.

- The Effect of SD on CS of ShopeePay users in Indonesia SD has a positive and significant effect on CS of ShopeePay users in Indonesia, which means that $\mathrm{H} 3$ is accepted. 
- The Effect of SI on CL of ShopeePay users in Indonesia

SI has a positive and insignificant effect on CL of ShopeePay users in Indonesia, which means that $\mathrm{H} 4$ is rejected.

- The Effect of CS on CL of ShopeePay users in Indonesia

CS has a positive and significant effect on CL of ShopeePay users in Indonesia, which means that $\mathrm{H} 5$ is accepted.

- The Effect of SD on CL of ShopeePay users in Indonesia

SD has no significant positive effect on CL of ShopePay users in Indonesia, which means that $\mathrm{H} 6$ is rejected.

Based on the analysis, it was also found that two of the three mediation effects were significant, namely (1) CS fully mediated the relationship between SI and CL and (2) CS partially mediated the relationship between SD and CL. Meanwhile, one mediating effect, namely SD fully mediates the relationship between SI and CL is not significant.

In Table 6, a comparison is shown between the results of hypothesis testing from previous research which became the reference with the results of hypothesis testing from this study.

Table 6. Comparison of Research Results

\begin{tabular}{lcc}
\hline Research Hypothesis & $\begin{array}{c}\text { YuSheng and } \\
\text { Ibrahim (2019) }\end{array}$ & $\begin{array}{c}\text { This Research } \\
(2020)\end{array}$ \\
\hline H1. SI has a positive and significant effect on SD & Accepted & Rejected \\
H2. SI has a positive and significant effect on CS & Accepted & Accepted \\
H3. SD has a positive and significant effect on CS & Accepted & Accepted \\
H4. SI has a positive and significant effect on CL & Accepted & Rejected \\
H5. CS has a positive and significant effect on CL & Accepted & Accepted \\
H6. SD has a positive and significant effect on CL & Accepted & Rejected \\
\hline
\end{tabular}

\subsection{Theoretical Implications}

This study contributes to the existing literature on the importance of service innovation (SI), service delivery (SD), and customer satisfaction (CS) theories on the development of customer loyalty (CL) theory in the context of e-wallet in Indonesia. As previously discussed, this study provides a new view of previous research findings which are expected to contribute to the development of Entrepreneurship and Marketing knowledge, namely that SI and SD by e-wallet provider ShopeePay in Indonesia will be able to significantly increase CL if they have a relationship that is positive with CS. In order to achieve competitive advantage, this study provides an overview of theoretical support that in carrying out SI and SD, it is necessary to pay attention to the needs and feedback from users in order to build a positive relationship in which users become satisfied with the experience of use, and then become loyal. This means that CL from ShopeePay e-wallet in Indonesia can be managed by business organizations indirectly through the provision of an innovative platform that is effective in providing services to users and has a system according to user needs.

\subsection{Managerial Implications}

Based on the findings after data analysis, this study proposes the following contributions to ShopeePay management in Indonesia so that they can remain competitive and sustainable through increased customer loyalty (CL) by taking into account several things:

- ShopeePay management must increase investment in research and development, technology, and human resources, especially the development team, business functions, and design to improve operational systems, provide easy and simple service processes, and 
ensure that there are no errors when users access ShopeePay services so as to reduce incidents of user complaints related to new and existing service features.

- Ease of use, ease of top up, and real time top up time can be maintained with continuous SI from ShopeePay e-wallet management in Indonesia which will then improve CS through positive user experiences.

- The speed in making transactions offered by ShopeePay e-wallet in Indonesia, such as real time top up system supported by a structured SD which then increases CS. It is important for ShopeePay management to pay attention to the transaction speed of the service which is one of the most important service attributes for e-wallets. In addition, ShopeePay management also needs to be involved in continuous training for frontline staff regarding the provision of necessary solutions in the event of a complaint related to SD so that customer complaints can be adequately and well responded to and handled so that users will be satisfied with ShopeePay services both in terms of use and after use.

- The existence of SI procurement such as face recognition supports the ease of use of ShopeePay e-wallet in online shopping which is able to boost user satisfaction levels, and in the end it also encourages CL. In holding SI which includes technological innovation, cooperation with telecommunication companies, internet service providers, and banks must be properly maintained by ShopeePay management so that services can continue to be used by users in meeting their needs. ShopeePay management must formulate a plan to continue to get feedback from the three parties accompanied by regular meetings to effectively improve service provision, because users need some time to turn loyal so ShopeePay Indonesia's management must ensure that SI is consistent in order to reach CS which later generates CL.

- It is important for ShopeePay Indonesia's management to continue to ensure CS of e-wallet users through consistency of ease of use, ease of real time top ups, and many promo offers so that CL can be maintained and even increased.

- In order to improve CS through SD so that CL is formed, ShopeePay management must work together to eliminate the causes of direct complaints related to services that indicate that users are not satisfied, namely by ensuring that ShopeePay services including its features are of good quality, and do not require long time to access.

\subsection{Research Limitations}

Based on the research method, the results of data analysis, and the discussion previously described, this study has the following limitation. The data in this study were collected by distributing a questionnaire in an online Google Form which was carried out during the COVID-19 pandemic and the transition to the new normal, where there was an increase in transactions on the marketplace because people needed to meet their daily needs during the pandemic without the need to go out and be encouraged by many promotional offers by ecommerce players. Data collection is cross-sectional (two months), it does not allow research to observe phenomena, behavior or opinions of respondents before and after changes related to the measured variables, namely when before the COVID-19 pandemic and after the COVID19 pandemic occurred or towards new normal. This study recognizes that the relationship under test may have some dynamic aspects that have been neglected.

\subsection{Further Research Suggestions}

Further research can be carried out the development of similar research in different contexts (for example: users of other e-wallet players in Indonesia, such as OVO, Gopay, 
DANA, and LinkAja with more diverse ages) and ensure that the proportion of respondents who live in different cities in Indonesia is almost the same to strengthen the implications of research construction in the e-wallet sector innovation literature. Future research can consider other variables that might affect CL in addition to the variables observed in this study, such as perceived value (Seesaiprai, 2016), core offer and switching costs (Lawton, 2016), handling of customer issues (Gupta and Singh, 2017), ease of use, privacy, and security (Octabriyantiningtyas et al., 2019), and then testing the extent to which they affect the output variables.

\section{REFERENCES}

Abror, A., Patrisia, D., Engriani, Y., Evanita, S., Yasri, Y., and Dastgir, S. (2019). Service Quality, Religiosity, CS, Customer Engagement and Islamic Bank's CL. Journal of Islamic Marketing, 1-15. https://doi.org/10.1108/JIMA-03-2019-0044

Adjei, J. K., Odei-Appiah, S., and Tobbin, P. E. (2019). Explaining the Determinants of Continual Use of Mobile Financial Services. Digital Policy, Regulation and Governance , 22(1), 15-31. https://doi.org/10.1108/DPRG-09-2019-0074

Agung, B. (2020, November). Survei Ipsos Soroti Tingkat Kepuasan Pengguna terhadap Layanan Dompet Digital di E-commerce. Dailysocial.Id.

Al-Msallam, S. (2015). The Relationship Between CS and CL in the Banking Sector in Syria. Journal of Marketing and Consumer Research, 7, 27-34.

Amankwah, O., Choong, W. W., and Mohammed, A. H. (2019). Modelling the Influence of Healthcare Facilities Management Service Quality on Patients Satisfaction. Journal of Facilities Management, 17(3), 267-283. https://doi.org/10.1108/JFM-08-2018-0053

Ameme, B., and Wireko, J. (2016). Impact of Technological Innovations on Customers in the Banking Industry in Developing Countries. In The Business and Management Review (Vol. 7).

Amin, M. (2016). Internet Banking Service Quality and Its Implication on E-CS and E-CL. International Journal of Bank Marketing, 34(3), 280-306. https://doi.org/10.1108/IJBM10-2014-0139

Antanegoro, R. Y., Surya, D., and Sanusi, F. (2017). Analisis Pengaruh Inovasi Produk, Inovasi Layanan. Jurnal Riset Bisnis Dan Manajemen Tirtayasa, 1(2), 167-179.

Awasthi, S., Euart, J., Hutchinson, D., and Kumar, S. (2020, June). Financial Decision-Maker Sentiment: Indonesia. McKinsey \& Company.

Azizah, N., Handayani, P. W., and Azzahro, F. (2018). Factors Influencing Continuance Usage of Mobile Wallets in Indonesia. Proceedings of 2018 International Conference on Information Management and Technology, ICIMTech 2018, 92-97. https://doi.org/10.1109/ICIMTech.2018.8528157

Bagas, F. (2020, August). ShopeePay Resmi Hadir sebagai Dompet Digital, Tawarkan Promo Voucher Belanja Rp 1. Nextren.

Bagla, R. K., and Sancheti, V. (2018). Gaps in CS With Digital Wallets: Challenge for Sustainability. Journal of Management Development, 37(6), 442-451. https://doi.org/10.1108/JMD-04-2017-0144

Blackmore, E., Vorley, B., Molenaar, J. W., Gorter, J., Heilbron, L., Simons, L., and Dallinger, J. (2015). SD How to Design an Effective Service Sector to Drive Sustainability in Smallholder Dominated Sectors. Aidenvironment, NewForesight, IIED. 
Blunch, N. J. (2008). Introduction to Structural Equation Modelling Using SPSS and Amos. In SAGE Publications Ltd (1st ed.). SAGE Publications Ltd.

Budiman, J. (2015). Corporate Governance, Capital Structure and Shareholder Value of Indonesian Stock Exchange Firms. Jurnal Manajemen Maranatha, 15(1), 75-94.

Cambridge English Dictionary. (2020a, July). CS. Cambridge English Dictionary.

Cambridge English Dictionary. (2020b, July). Satisfaction. Cambridge English Dictionary.

Cambridge English Dictionary. (2020c, July). SD . Cambridge English Dictionary.

Chen, M. C., Chang, K. C., Hsu, C. L., and Yang, I. C. (2011). Understanding the Relationship Between Service Convenience and CS in Home Delivery by Kano Model. Asia Pacific Journal of Marketing and Logistics, 23(3), 386-410. https://doi.org/10.1108/13555851111143277

Chu, P. Y., Lee, G. Y., and Chao, Y. (2012). Service Quality, CS, Customer Trust, and Loyalty in an E-Banking Context. Social Behavior and Personality, 40(8), 1271-1284. https://doi.org/10.2224/sbp.2012.40.8.1271

Ciuchita, R., Mahr, D., and Odekerken-Schröder, G. (2019). "Deal With It": How Coping With E-SI Affects the Customer Experience. Journal of Business Research, 103, 130-141. https://doi.org/10.1016/j.jbusres.2019.05.036

Dachyar, M., Syahbana Rusli, M., and Yuri Zagloel, T. M. (2013). The Role of Innovation Management Model to Improve Service Quality for Telecommunications Industry in Indonesia. Innovative Systems Design and Engineering, 4(4), 1-6.

Dawi, N. M., Jusoh, A., Streimikis, J., and Mardani, A. (2018). The Influence of Service Quality on CS and Customer Behavioral Intentions by Moderating Role of Switching Barriers in Satellite Pay TV Market. Recent Issues In Sociological Research Economics and Sociology, 11(4), 198-218. https://doi.org/10.14254/2071

Demoulin, N. T. M., and Djelassi, S. (2013). Customer Responses to Waits for Online Banking SD. International Journal of Retail and Distribution Management, 41(6), 442-460. https://doi.org/10.1108/09590551311330825

Dholakia, R. R., and Zhao, M. (2010). Effects of Online Store Attributes on CS and Repurchase Intentions. International Journal of Retail and Distribution Management, 38(7), 482-496. https://doi.org/10.1108/09590551011052098

Diaw, B., and Asare, G. (2018). Effect of Innovation on CS and Customer Retention in the Telecommunication Industry in Ghana: Customers' Perspectives. European Journal of Research and Reflection in Management Sciences, 6(4).

Durst, S., Mention, A. L., and Poutanen, P. (2015). SI and Its Impact: What Do We Know About? Investigaciones Europeas de Direccion y Economia de La Empresa, 21(2), 6572. https://doi.org/10.1016/j.iedee.2014.07.003

Estiri, M., Hosseini, F., Yazdani, H., and Javidan Nejad, H. (2011). Determinants of CS in Islamic Banking: Evidence from Iran. International Journal of Islamic and Middle Eastern Finance and Management, 4(4), 295-307. https://doi.org/10.1108/17538391111186546

Fernandes, A. A. R., and Solimun, S. (2018). The Mediation Effect of CS in the Relationship Between Service Quality, Service Orientation, and Marketing Mix Strategy to CL. Journal of Management Development, 37(1), 76-87. https://doi.org/10.1108/JMD-122016-0315 
Firmansyah, L. M. (2020, February). Sambil Berinovasi, Dompet Digital Harus Jaga Data Pribadi. Lokadata.Id.

Firmansyah, R. (2020, November). Survei: ShopeePay dan OVO Jadi Dompet Digital dengan Pelanggan Setia Terbanyak . KumparanBisnis.

Fornell, C., and Larcker, D. F. (1981). Evaluating Structural Equation Models With Unobservable Variables and Measurement Error. Journal of Marketing Research, 18(1), 39. https://doi.org/10.2307/3151312

Fraering, M., and Minor, M. S. (2013). Beyond Loyalty: CS, Loyalty, and Fortitude. Journal of Services Marketing, 27(4), 334-344. https://doi.org/10.1108/08876041311330807

Furunes, T., and Mkono, M. (2019). Service-Delivery Success and Failure Under the Sharing Economy. International Journal of Contemporary Hospitality Management, 31(8), 33523370. https://doi.org/10.1108/IJCHM-06-2018-0532

Ganzer, P. P., Chais, C., and Olea, P. M. (2017). Product, Process, Marketing and Organizational Innovation in Industries of the Flat Knitting Sector. RAI Revista de Administração e Inovação, 14(4), 321-332. https://doi.org/10.1016/j.rai.2017.07.002

Gupta, O. J., and Singh, A. (2017). Impact of Relationship Management on CL of E-Wallet Users: A Study of Paytm Enterprise. SMS Journal of Entrepreneurship and Innovation, 3(2), 42-50. https://doi.org/10.21844/smsjei.v3i02.9739

Hair, Joe F., Ringle, C. M., and Sarstedt, M. (2011). PLS-SEM: Indeed a Silver Bullet. Journal of Marketing Theory and Practice, 19(2), 139-152. https://doi.org/10.2753/MTP10696679190202

Hair, Joseph F., Black, W. C., Babin, B. J., and Anderson, R. E. (2014). Multivariate Data Analysis (7th Ed.). Pearson Education Limited.

Harususilo, Y. E. (2020, April). Menristek: Sektor Digital Jadi Substitusi Penting di Tengah Wabah COVID-19 . Kompas.

Hasnan, L. (2019, July 17). Getting Creative in Indonesia. The ASEAN Post. https://theaseanpost.com/article/getting-creative-indonesia

Henry. (2020, August). Pembayaran Digital Makin Diminati, Transaksi ShopeePay Naik 5 Kali Lipat . Liputan6.Com.

Ipsos. (2020). Evolusi Industri Dompet Digital: Strategi Menang Tanpa Bakar Uang.

Isna, T. D. (2019, July). Revolusi Industri 4.0: SDM dan Inovasi adalah Kunci. Warta Ekonomi.

Johnston, R., Clark, G., and Shulver, M. (2012). Service Operations Management: Improving $S D$ (4th Ed.). Pearson.

Kandampully, J., Zhang, T. (Christina), and Bilgihan, A. (2015). CL: A Review and Future Directions With a Special Focus on the Hospitality Industry. International Journal of Contemporary Hospitality Management, 27(3), 379-414. https://doi.org/10.1108/IJCHM-03-2014-0151

Kapferer, J.-N. (2005). The Roots of Brand Loyalty Decline: An International Comparison. Ivey Business Journal, 69(4), 1-6.

Khadka, K., and Maharjan, S. (2017). CS and CL.

Kontan. (2020, August). ShopeePay Tumbuh Paling Pesat dan Menjadi Fitur Layanan EMoney Nomor 1 di Indonesia. Kontan.

Krumay, B., and Brandtweiner, R. (2010). Are Customer Service Offerings Influencing ELoyalty? A Graphical Chain Model Approach in the Austrian Mobile Phone Service 
Provider Industry. 23rd Bled EConferencee ETrust: Implications for the Individual, Enterprises and Society, 346-363.

Kumar, R., Sachan, A., and Kumar, R. (2020). Impact of SD System Process and Moderating Effect of Perceived Value in Internet Banking Adoption. Australasian Journal of Information Systems, 24, 1-22. https://doi.org/10.3127/ajis.v24i0.1923

Kumar, V., Batista, L., and Maull, R. (2011). The Impact of Operations Performance on CL. The Impact of Operations Performance on CL Service Science, 3(2), 158-171. https://doi.org/10.1287/serv.3.2.158

Kurniawan, B., Nirwanto, N., and Firdiansjah, A. (2019). The Effect of SI on CS Indihome Internet Provider in Central Java through Corporate Reputation as Variable Intervening. International Journal of Scientific and Technology Research, 8(10).

Kusdibyo, L., and Februadi, A. (2019). The Effect of Electronic Service Quality on Customers Satisfaction and Loyalty in Online Shopping. IOP Conf. Series: Materials Science and Engineering, 1-8. https://doi.org/10.1088/1757-899X/662/2/022036

Lawton, R. (2016, January). What Factors Influence CL? Arrk Group.

Leninkumar, V. (2017). The Relationship Between CS and Customer Trust on CL. International Journal of Academic Research in Business and Social Sciences, 7(4), 450. https://doi.org/10.6007/IJARBSS/v7-i4/2821

Lin, L. (2011). The Impact of SI on Business Performance: Evidence from Firm-Level Data in Chinese Tourism Sector. 8th International Conference on Service Systems and Service Management Proceedings of ICSSSM'11. https://doi.org/10.1109/ICSSSM.2011.5959499

Mahlil, M. I. (2019, July). Cara GoPay dan OVO Meraih Laba . Kompasiana.

Mahmoud, M. A., Hinson, R. E., and Anim, P. A. (2018). SI and CS: The Role of Customer Value Creation. European Journal of Innovation Management, 21(3), 402-422. https://doi.org/10.1108/EJIM-09-2017-0117

Martins, N., and Ledimo, O. (2015). The Perceptions and Nature of SD Innovation Among Government Employees: An Exploratory Study. Journal of Governance and Regulation, 4(4), 575-580. https://doi.org/10.22495/jgr_v4_i4_c5_p1

Mary, D. M., and Henshaw, A. G. (2020). SD Strategies and Customers' Loyalty to Online Retailers in Rivers State. Journal of Contemporary Marketing, 5(1).

Mihardjo, L. W. W., Sasmoko, S., Alamsjah, F., and Elidjen, E. (2019). Impact of Green IS, SI and Customer Experience in Influencing CS and Environmental Performance. International Journal of Energy Economics and Policy, 9(6), 379-385. https://doi.org/10.32479/ijeep.8371

Minh, N. V., and Huu, N. H. (2016). The Relationship Between Service Quality, CS and CL: An Investigation in Vietnamese Retail Banking Sector. Journal of Competitiveness, 8(2), 103-116. https://doi.org/10.7441/joc.2016.02.08

Mittal, B., and Lassar, W. M. (1998). Why Do Customers Switch? The Dynamics of Satisfaction Versus Loyalty. Journal of Services Marketing, 12(3), 177-194. https://doi.org/10.1108/08876049810219502

MSN, S. (2020, February 12). Ipsos Media Conference - Strategi Menang Tanpa Bakar Uang - Ipsos. https://www.ipsos.com/en-id/ipsos-media-conference-strategi-menang-tanpabakar-uang 
Musaad, A. (2020, June). Dampak COVID-19 terhadap Penggunaan E-Wallet. OKnews.

Musara, M., and Fatoki, O. (2010). Has Technological Innovations Resulted in Increased Efficiency and Cost Savings for Banks' Customers? African Journal of Business Management, 4(9), 1813-1821.

Narteh, B. (2015). Perceived Service Quality and Satisfaction of Self-Service Technology: The Case of Automated Teller Machines. International Journal of Quality and Reliability Management, 32(4), 361-380. https://doi.org/10.1108/IJQRM-08-2012-0113

Naveed, T., Akhtar, I., and Cheema, K. U. R. (2012). The Impact of Innovation on CS and Brand Loyalty: A Study of the Students of Faisalabad.

Nefat, A., Benazic, D., and Aleric, D. (2012). Antecedents and Outcomes of Service Recovery Satisfaction in Telecommunications in Croatia Along with the Role of Image and Perceived Switching Costs. Economic Research-Ekonomska Istrazivanja, 25(4), 10511066. https://doi.org/10.1080/1331677X.2012.11517547

Ngo, L. V., and O'Cass, A. (2013). Innovation and Business Success: The Mediating Role of Customer Participation. Journal of Business Research, 66(8), 1134-1142. https://doi.org/10.1016/j.jbusres.2012.03.009

Nguyen, N. T., Tran, T. T., and Wang, C. N. (2014). An Empirical Study of CS Towards Bank Payment Card Service Quality in Ho Chi Minh Banking Branches. International Journal of Economics and Finance, 6(5). https://doi.org/10.5539/ijef.v6n5p170

Nienaber, H. (2010). Customer Service: Quo Vadis?

Octabriyantiningtyas, D., Suryani, E., and Jatmiko, A. R. (2019). Modeling CS With the Service Quality of E-Money in Increasing Profit of PT. Telekomunikasi Indonesia. Procedia Computer Science, 161, 943-950. https://doi.org/10.1016/j.procs.2019.11.203

Oliver, R. L. (1999). Whence Consumer Loyalty? Journal of Marketing, 63(SUPPL.), 33-44. https://doi.org/10.2307/1252099

Omoregie, O. K., Addae, J. A., Coffie, S., Ampong, G. O. A., and Ofori, K. S. (2019). Factors Influencing Consumer Loyalty: Evidence From the Ghanaian Retail Banking Industry. International Journal of Bank Marketing, 37(3), 798-820. https://doi.org/10.1108/IJBM04-2018-0099

Ordanini, A., and Parasuraman, A. (2011). SI Viewed Through a Service-Dominant Logic Lens: A Conceptual Framework and Empirical Analysis. Journal of Service Research, 14(1), 3-23. https://doi.org/10.1177/1094670510385332

Othman, A. K., Hamzah, M. I., and Abu Hassan, L. F. (2020). Modeling the Contingent Role of Technological Optimism on CS With Self-Service Technologies. Journal of Enterprise Information Management, 33(3), 559-578. https://doi.org/10.1108/JEIM-09-2019-0295

Özkan, P., Süer, S., Keser, İ. K., and Kocakoç, İ. D. (2019). The Effect of Service Quality and CS on CL. International Journal of Bank Marketing, 38(2), 384-405. https://doi.org/10.1108/IJBM-03-2019-0096

Pantouvakis, A., and Bouranta, N. (2013). The Link Between Organizational Learning Culture and CS: Confirming Relationship and Exploring Moderating Effect. Learning Organization, 20(1), 48-64. https://doi.org/10.1108/09696471311288528

Prasetyo, W. B. (2020, August). Ini Daftar Dompet Digital dengan Pertumbuhan Pesat Saat Pandemi. Berita Satu.

PricewaterhouseCoopers. (2007). The Road Ahead for Public SD Delivering on the Customer 
Promise*.

Quality, A. S. for. (n.d.). What is CS? American Society for Quality.

Rafaeli, A., Altman, D., Gremler, D. D., Huang, M.-H., Grewal, D., Iyer, B., Parasuraman, A., and de Ruyter, K. (2016). The Future of Frontline Research: Invited Commentaries. Journal of Service Research, 20(1), 91-99. https://doi.org/10.1177/1094670516679275

Ranabhat, D. (2018). CL in Business.

Rubalcaba, L., Aboal, D., and Garda, P. (2016). SI in Developing Economies: Evidence from Latin America and the Caribbean. Journal of Development Studies, 52(5), 607-626. https://doi.org/10.1080/00220388.2015.1093118

Salameh, A. A. M., Ahmad, H., Zulhumadi, F., and Abubakar, F. M. (2018). Relationships Between System Quality, Service Quality, and CS: M-Commerce in the Jordanian Context. Journal of Systems and Information Technology, 20(1), 73-102. https://doi.org/10.1108/JSIT-03-2017-0016

Schulte-Brüggemann, P., Streit, Y., and Kurtmollaiev, S. (2018). SI, Customer-Perception and Loyalty: An Experiment How Does Customer-Perceived SI Affect CL? Norwegian School of Economics .

Schwab, K. (2011). The Global Competitiveness Report 2011-2012.

Seesaiprai, S. (2016). The Effects of SI and Service Quality on Customer's Loyalty in Small Service Enterprise: A Case Study on Car Care Business in Bangkok. Review of Integrative Business and Economics Research, 5(1), 296.

Sekaran, U., and Bougie, R. (2016). Research Methods for Business: A Skill Building Approach, 7th Edition (7th Ed.). Wiley.

Senbabaoglu, E. (2017). The Impact of the Service Innovativeness on Perceived Overall Service Quality, CL and Perceived Customer Value in Shopping Sites. Marketing and Branding Research, 4, 371-383.

Setyowati, D. (2019). Persaingan Bisnis Dompet Digital Makin Ketat dan Mengerucut Startup Katadata.co.id.

Setyowati, D. (2020, September). ShopeePay Punya Tiga Strategi Menantang Dominasi GoPay dan OVO. Katadata.Co.Id.

Silaen, E., and Prabawani, B. (2019). Pengaruh Persepsi Kemudahan Menggunakan E-Wallet dan Persepsi Manfaat serta Promosi terhadap Minat Beli Ulang Saldo E-Wallet OVO. Jurnal Ilmu Administrasi Bisnis, 8(4), 155-163.

Singh, N., Sinha, N., and Liébana-Cabanillas, F. J. (2020). Determining Factors in the Adoption and Recommendation of Mobile Wallet Services in India: Analysis of the Effect of Innovativeness, Stress to Use and Social Influence. International Journal of Information Management, 50, 191-205. https://doi.org/10.1016/j.ijinfomgt.2019.05.022

Sofuroh, F. U. (2020, August). ShopeePay Jadi E-Wallet dengan Perkembangan Terpesat Selama Pandemi. DetikInet.

Stenberg, A. (2017). What Does Innovation Mean-A Term Without a Clear Definition.

Sugiarto, E. C. (2018, November 13). Ekonomi Kreatif Masa Depan Indonesia. Kementerian Sekretariat Negara

RI. https://www.setneg.go.id/baca/index/ekonomi_kreatif_masa_depan_indonesia

Suhartanto, D., Helmi Ali, M., Tan, K. H., Sjahroeddin, F., and Kusdibyo, L. (2019). Loyalty Toward Online Food Delivery Service: The Role of E-Service Quality and Food Quality. 
Journal of Foodservice Business Research, 22(1), 81-97. https://doi.org/10.1080/15378020.2018.1546076

Supriyanto, B. (2020, August). Saat Pandemi, ShopeePay Jadi E-Wallet yang Tumbuh Paling Pesat. Bisnis.Com.

Tao, F. (2014). Customer Relationship Management Based on Increasing CS. International Journal of Business and Social Science, 5(5).

Taylor, S. P. (2017). What Is Innovation? A Study of the Definitions, Academic Models and Applicability of Innovation to an Example of Social Housing in England. https://doi.org/10.4236/jss.2017.511010

Terpstra, M., Kuijlen, T., and Sijtsma, K. (2013). How to Develop a CS Scale With Optimal Construct Validity. Quality and Quantity, 48(5), 2719-2737. https://doi.org/10.1007/s11135-013-9920-7

Thuy, P. N., and Hau, L. N. (2010). Service Personal Values and CL: A Study of Banking Services in a Transitional Economy. International Journal of Bank Marketing, 28(6), 465-478. https://doi.org/10.1108/02652321011077706

Trott, P. (2017). Innovation Management and New Product Development (6th Ed.). Pearson.

Uchenna, L., Omankhanlen, A. E., Okoh, J. I., Ezeji, F. N., and Achugamonu, U. B. (2019). Imperatives for Deepening Customer SD in the Nigerian Banking Sector Through Engineering and Technology-Based Channels. International Journal of Civil Engineering and Technology, 10(01), 2156-2169.

Wambugu, D., Wachira, M., and Mwamba, D. (2016). The Effect of Innovation on SD in the Public Sector in Kenya. International Journal of Business Strategies, 2(2), 1-21.

Widodo, M., Irawan, M. I., and Sukmono, R. A. (2019). Extending UTAUT2 to Explore Digital Wallet Adoption in Indonesia. 2019 International Conference on Information and $\begin{array}{llll}\text { Communications } & \text { Technology, } & \text { ICOIACT } & \text { 2019, 878-883. }\end{array}$ https://doi.org/10.1109/ICOIACT46704.2019.8938415

Wong, A. (2019, October 31). One of Malaysia's first eWallets bites the dust . SoyaCincau.Com. https://www.soyacincau.com/2019/10/31/digi-vcash-ewallet-shutsdown/

Writer, M. (2018, December 18). Mengenal Lebih dalam tentang Industri Kreatif dan Startup. https://www.kompasiana.com/angelsari/5c189e0ec112fe683c5e0237/mengenallebih-dalam-tentang-industri-kreatif-dan-start-up

Wu, C. W. (2014). The Study of SI for Digiservice on Loyalty. Journal of Business Research, 67(5), 819-824. https://doi.org/10.1016/j.jbusres.2013.11.051

Yadav, M. P., and Arora, M. (2018). A Study on Impact on CS for E-Wallet Using Path Analysis Model. Proceedings of 4th International Conference on Computers and Management (ICCM) 2018.

Yoga, A. (2020, June). Semua yang Perlu Kamu Tahu Soal Dompet Digital atau E-Wallet. Cosmopolitan.

YuSheng, K., and Ibrahim, M. (2019). SI, SD and CS and Loyalty in the Banking Sector of Ghana. International Journal of Bank Marketing, 37(5), 1215-1233. https://doi.org/10.1108/IJBM-06-2018-0142 


\section{APPENDIX}

\section{Scales Used in the Study}

Service innovation (Mahmoud et al., 2018)

1) ShopeePay service uses modern interaction media

2) ShopeePay service offers fast call center support within the app

3) ShopeePay service offers easy in-app call center support

Service delivery (Ba and Johansson, 2008 in Kumar et al., 2020)

1) I had a hard time finding what I was looking for on ShopeePay service

2) The whole search process in ShopeePay service takes a LONG time

3) The entire transaction process in ShopeePay service takes a LONG time

4) The ShopeePay service is DIFFICULT to navigate

Customer Satisfaction (Nefat et al., 2012, Bhattacherjee, 2001 in Othman et al., 2020, Dawi et al., 2018)

1) I am satisfied with my overall experience with ShopeePay service

2) I think I did the right thing when choosing ShopeePay service

3) My choice to use ShopeePay service was right

4) I am satisfied with my decision to use ShopeePay service

5) Overall, I am happy with ShopeePay service that I have

6) ShopeePay service lives up to my expectations

Customer Loyalty (Oliver, 1999, Cheng et al., 2008 in Thuy and Hau, 2010, Özkan et al., 2019)

1) I am committed to use ShopeePay service

2) If I need another type of electronic money service, I will choose ShopeePay

3) I would recommend ShopeePay to others who ask me for advice

4) I will continue to use ShopeePay service

5) I only pay attention to ShopeePay

6) I will continue to use ShopeePay even though the transaction fees of other e-money providers are lower

7) I feel loyal to ShopeePay

8) I believe that ShopeePay is the best app brand in the e-money sector 